\title{
Engineering economic analysis of meliponiculture in Malaysia considering current market price
}

\author{
Firdaus Basrawi ${ }^{1 *}$, Asnul Hadi Ahmad ${ }^{1}$, Daing Mohamad Nafiz Daing Idris ${ }^{1}$, Mohd \\ Rashidi Maarof ${ }^{l}$, MRR Chand ${ }^{l}$ and Ahmad Syazwan Ramli ${ }^{l}$ \\ 1 Meliponini Engineering Laboratory (MePEL), Energy Sustainability Focus Group (ESFG), \\ Faculty of Mechanical Engineering, Universiti Malaysia Pahang.
}

\begin{abstract}
Stingless bees (kelulut) keeping is now a trend in Malaysia. However, since demand for the source of colony in log is increasing, the log price is rapidly increasing. But, there is no data reported on the economic viability of meliponiculture in the current market price. Thus, the objective of this study is to clarify the economic viability of investment in meliponiculture in the current market price by engineering economic perspective. Investment in meliponiculture was analysed using Equivalent Annual Uniform Cost (EAUC), Internal Rate of Return (IRR) and Breakeven Analysis. A small start-up with 30 units of logs or hives was considered in the analysis. All raw data was acquainted from current Malaysian market price, but only revenue from honey was considered. It was found that EAUC indicated that the annual worth of the $\log$ system is $23 \%$ better than the hive system. However, IRR calculation indicated that both the log and the hive systems offer margin exceeding 55\% which is a very good return in general investment. In addition, it was also found that the log system had breakeven after 8th month, whereas the hive was 13th month. Better economic value could be obtained if revenue from by-products are considered. Thus, it can be concluded that meliponiculture is still very economically viable in Malaysia market trend, and the hive systems could be a better choice if splitting colony, maintenance, safety and aesthetics points of view are considered.
\end{abstract}

\section{Introduction}

Bee keeping is a traditional culture in getting honey in tropical climate country. For Malaysia, it is recorded that bee keeping has established since Malacca Sultanate era (Hassan, Z., 2003). However, it is believed that bee keeping has been practiced earlier than that in Malaysia. Bee keepers preferred Apis bees than stingless bees because the honey production for stingless bee is too little, and it is well known that the stingless bees honey could not be commercialized in a large-scale (Jaafar, 2012; Ismail, 2012). However, stingless bees honey is getting high demand and has high commercial value in Malaysia because it is an alternative to the widespread adulterated honey in the country, and also because of its better health benefit than Apis honey (Ismail, 2014; Idris, 2013; Jaafar, 2011b). In addition, high commercial value of by-products from meliponiculture including propolis and bee bread, and government support through funding and research in public institutions also contribute to the grow of industrialization of meliponiculture. Bee keepers

\footnotetext{
*Corresponding author: mfirdausb@ump.edu.my
} 
usually obtain a colony from Orang Asli to start the meliponiculture activity. The cost to have a log with topping or honey cassette was about RM100-150/log in 2010-2012, but now the price has increased to RM350-700/log.

Many new investors think about higher capital cost, and other challenges due to stolen logs, threats by overheat, animals and insects (Sinar Harian, 2016; Sinar Harian, 2015). There are also perception that it is currently not worthy to invest in meliponiculture under current market price. However, there is no clear data on the economic analysis of meliponiculture under current market. Thus, the objective of this study is to investigate the economic viability of investment in meliponiculture in the current market price by engineering economic perspective. Investment in meliponiculture was analyzed using Equivalent Annual Uniform Cost (EAUC), Internal Rate of Return (IRR) and Breakeven Analysis. A small start-up with 30 units of log or hive were considered in the calculation. EAUC, IRR and Breakeven Analysis was applied to determine the comparison of annual operating cost, the exact operational margin, and the breakeven time consensus depending on fixed and variable cost.

\section{Material and method}

The first common evaluation in engineering economic is by Equivalent Annual Uniform Cost (EAUC). It is used to determine the equal opportunity of investment suitability. The objective is to convert money into an equivalent uniform cost in a year. The main advantage of EAUC is that it could compare different investments that have different lifetime. This is because it is an equivalent annual cost over the lifetime of the project. The parameter used in the calculation is shown in Table 1. Data used are value in the current market. It should be noted that hive system includes a mounting system, and data shown for labor, maintenance, rental, revenue are annual data.

Table 1. The parameter considered in EAUC method

\begin{tabular}{|c|c|c|}
\hline Type & Log & Hive \\
\hline $\begin{array}{c}\text { Purchasing cost (RM) } \\
\text { Logs } \\
\text { Fence }\end{array}$ & $\begin{array}{c}450 \times 30=13,500 \\
5,000\end{array}$ & $\begin{array}{c}90 \times 30=27,000 \\
5,000\end{array}$ \\
\hline $\begin{array}{c}\text { Site Cleaning } \\
\text { Annual maintenance cost } \\
\text { (RM }\end{array}$ & 1,000 & 1,000 \\
\hline $\begin{array}{c}\text { Annual labour cost (RM) } \\
\text { Rent (RM) }\end{array}$ & 9,000 & 5,00 \\
\hline Sale value (RM) & 3,6000 & 9,000 \\
\hline Life (years) & 32,400 & 3,6000 \\
\hline
\end{tabular}

EAUC can be calculated by the following equation. 


$$
A W_{\text {Log }}=(A P, i, \% L T)-A_{\text {operation }}+A_{\text {revenue }}
$$

where AWlog is Annual Worth $[\mathrm{RM}], \mathrm{A} / \mathrm{P}$ is finding Annual operation cost and revenue in terms of present value [RM], $\mathrm{i}$ is expected dividend/ interest/ margin of the project in decimal, LT is lifetime of the investment [year], Aoperation is per annual expenditure due to operation $[\mathrm{RM}]$, and Arevenue is per annual revenue $[\mathrm{RM}]$ after sales.

Then, Internal Rate Return (IRR) was calculated to evaluate the relevance of the investment. IRR indicates the exact rate of return that is received on an investment. IRR is also defined as the investment rate that makes the Present Worth of all expenditures is equal to the Present Worth of all income, i.e., the Net Present Value (NPV) equals zero. To calculate the IRR, the NPV of all values are calculated as a function of the interest rate, and then interest rate that makes the NPV is equal to zero is calculated. IRR can be calculated by the following equation;

$$
\begin{gathered}
P W_{\text {Loss }}=P W_{\text {Gain }} \\
P W_{\text {Loss }}=A_{\text {operation }}(P / A, i, L T)-A_{\text {revenue }}(P / A, i, L T)
\end{gathered}
$$

where $P W$ is Present Worth [RM], $A_{\text {operation }}$ is per annual expenditure due to operation in negative value [RM], and $A_{\text {revenue }}$ is per annual revenue [RM] after sales, $P / A$ is finding Present worth of money, $P$ with given Annual operation and revenue cost [RM], $i$ is

\begin{tabular}{|c|c|c|c|}
\hline Cost & Type & $\log [\mathrm{RM}]$ & Hive $[R M]$ \\
\hline Fixed & Logs & $\begin{array}{c}450 \times 30= \\
13,500\end{array}$ & $\begin{array}{c}90 \times 30= \\
27,000\end{array}$ \\
\hline Fixed & Fence & 5,000 & 5,000 \\
\hline Fixed & Site Cleaning & 1,000 & 1,000 \\
\hline Fixed & $\begin{array}{l}\text { Annual maintenance cost } \\
\text { One-Off }\end{array}$ & 1,000 & 5,00 \\
\hline Fixed & $\begin{array}{l}\text { Annual labour cost (RM) } \\
\text { RM 750.00 Monthly }\end{array}$ & 9,000 & 9,000 \\
\hline Fixed & $\begin{array}{c}\text { Rent (RM) } \\
\text { RM } 300.00 \text { Monthly }\end{array}$ & 3,6000 & 3,6000 \\
\hline Revenue & Sale value $[\mathrm{RM} / \mathrm{kg}]$ & 300 & 300 \\
\hline Variable Cost & Bottle [ RM/ $100 \mathrm{ml}]$ & 2 & 2 \\
\hline Variable Cost & $\begin{array}{c}\text { Harvesting and Bottling } \\
\text { ( RM 100/ } 9 \mathrm{~kg} \text { which produce } \\
90 \text { bottle of } 100 \mathrm{ml} \text { capacity) } \\
100 / 9=\mathrm{RM} 11.11 / \mathrm{kg}\end{array}$ & 11.11 & 11.11 \\
\hline
\end{tabular}
expected dividend/ interest/ margin of the project, $L T$ is lifetime of the investment [year].

Table 2. Schedule for breakeven analysis 
Finally breakeven calculation was carried out to determine the payback period of the investment. Payback period is the period of time required for the revenue from an investment to equal the cost of the investment. The breakeven calculation based on given schedule shown in Table 2. It should be noted that more detail parameters were considered as compared to Table 1.

Payback Period in month $P B P_{\text {month }}$ could be obtained by the following equation;

$$
P B P_{\text {month }}=\frac{m_{B E}}{m_{\text {month }}}
$$

Where $m_{B E}$ of honey needed to achieve breakeven $[\mathrm{kg}], m_{m o n t h}$ is estimated mass of honey produced monthly $\left[\mathrm{kg}\right.$ ], and it is equal to [9 $\mathrm{kg} / \mathrm{month}$ ] for $30 \operatorname{logs}$ or hives. $m_{B E}$ could be calculated by Equation (5), and to achieve breakeven, the Total contribution T.Cont must be equal to Fixed Cost (FC) as shown in equation (6).

$$
\begin{aligned}
& m_{B E}=\frac{T . \text { Cont }}{\text { Cont }_{\text {perkg }}} \\
& \text { T.Cont }=F C
\end{aligned}
$$

where T.Cont is in [RM], and Cont $_{\text {perkg }}$ is Contribution per-kg $[\mathrm{RM} / \mathrm{kg}]$ is calculated by difference between revenue total variable cost per-kg shown in Equation (7).

$$
\text { Cont }_{\text {perkg }}=R E V_{\text {perkg }}-T V C_{\text {perkg }}
$$

where $R e v_{\text {perkg }}$ is revenue per-kg obtained from sales of honey [RM/kg], and $T V C_{\text {perkg }}$ is total variable cost per-kg of bottling and operational cost $[\mathrm{RM} / \mathrm{kg}]$. It should be noted that it takes time for colony to produce honey after honey cassette is placed to the log, or after colony is transferred to hive system. Thus, expected $1^{\text {st }}$ batch of the honey production is after four month with 0.3 [kg-honey/log/month] produced.

\section{Result}

\subsection{Equivalent annual uniform cost}

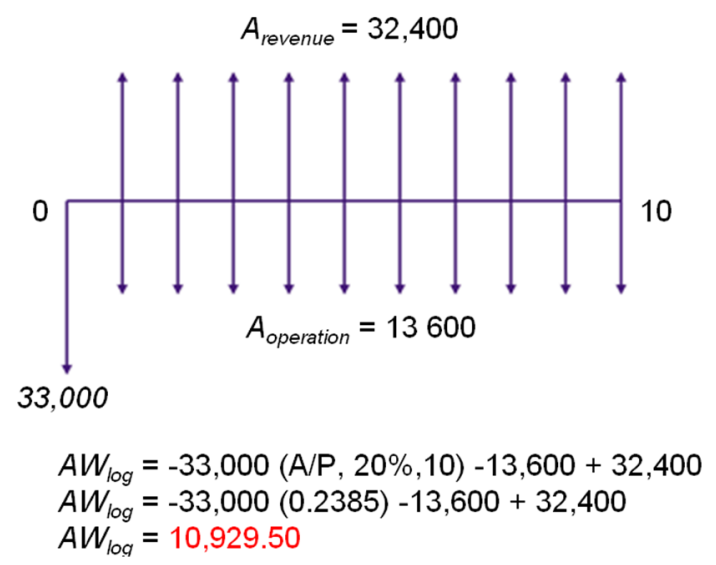

Fig. 1. EAUC for log system 


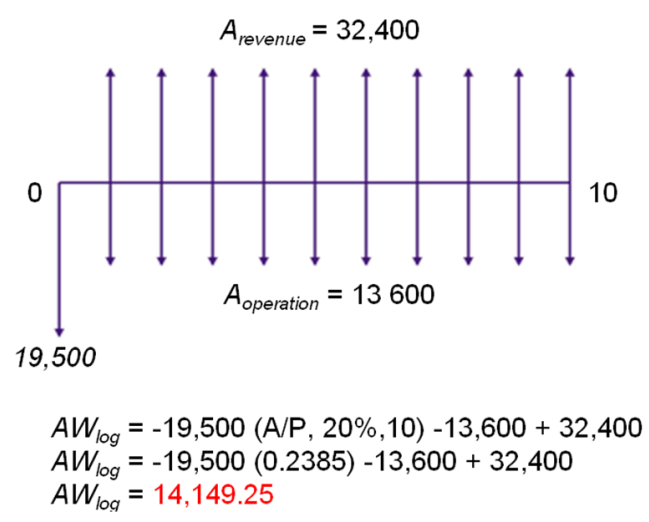

Fig. 2. EAUC for Hive system

Results of EAUC for log system and hive system is shown in Fig. 1 and Fig. 2, respectively. It shows that uniform revenue and variable operational cost is same because same production and operation was estimated for both systems. Since initial cost of $\log$ type is $40 \%$ cheaper, log system has $22.7 \%$ higher EAUC value than hive system for 10 years of lifecycle considered. However, the calculation never discusses the ease of maintenance and operation, splitting colony benefit of hive.

\subsection{Internal rate of return}

Results of IRR for $\log$ and hive systems is shown in Table 3 and Table 4, respectively. It was found that IRR for the log system is more than $69 \%$, whereas IRR for the hive system is $58.4 \%$. This indicates that both investments shows very high return and worth to invest. Even the lower IRR of hive system is actually very good for investment, although higher initial investment is required. Thus, both investment opportunity are very promising even in the current market price. If production of propolis, bee bread, and byproducts are considered, even higher return is expected from the investment.

$$
\begin{gathered}
P W_{\text {Loss }}=P W_{\text {Gain }} \\
19,500=13,600(P / A, i, 10)+32,400(P / A, i, 10) \\
19,500+13,600(P / A, i, 10)+32,400(P / A, i, 10)=0
\end{gathered}
$$

Table 3. IRR and NPV for log system

\begin{tabular}{|c|c|c|}
\hline When $\boldsymbol{i}[\%]$ & P/A (10) & NPV \\
\hline$i=20 \%$ & 4.192 & -59309.6 \\
\hline $\mathrm{i}=60 \%$ & 1.652 & -11557.6 \\
\hline
\end{tabular}

Then,

$$
\begin{gathered}
\frac{i-20}{60-20}=\frac{0-(-59309.6)}{-11557.56-59309.6} \\
i_{\log }=69.7 \%
\end{gathered}
$$




$$
\begin{gathered}
P W_{\text {Loss }}=P W_{\text {Gain }} \\
33,300=13,600(P / A, i, 10)+32,400(P / A, i, 10) \\
33,300+13,600(P / A, i, 10)+32,400(P / A, i, 10)=0
\end{gathered}
$$

Table 4. IRR and NPV for hive system

\begin{tabular}{|c|c|c|}
\hline When $\boldsymbol{i}[\%]$ & P/A (10) & NPV \\
\hline$i=20 \%$ & 4.192 & -45809.6 \\
\hline $\mathrm{i}=60 \%$ & 1.652 & 1942.6 \\
\hline
\end{tabular}

Then,

$$
\begin{gathered}
\frac{i-20}{60-20}=\frac{0-(-45809.6)}{1942.6-(-45809.6} \\
i_{\text {hive }}=58.4 \%
\end{gathered}
$$

\subsection{Breakeven and payback period}

Finally is the results of breakeven and payback period. Fig. 3 shows the breakeven of $\log$ and hive systems. As shown in Fig. 3, both systems starts to produce honey in 4th month of the life cycle. Since estimated production is same at $9 \mathrm{~kg} / \mathrm{month}$, payback period for $\log$ system is at 8.35 months, whereas for hive system is 13.56 months. Although hive system has longer period, but it is still can get payback within 14 months which is considered as a short payback period for an investment. Thus, meliponiculture is in general it is too good as an investment with high IRR and short payback period. If bee bread, propolis and by-products are considered, the payback period could be even shorter. Both systems is therefore economically viable enough to be invested in Malaysia even in the current market price.

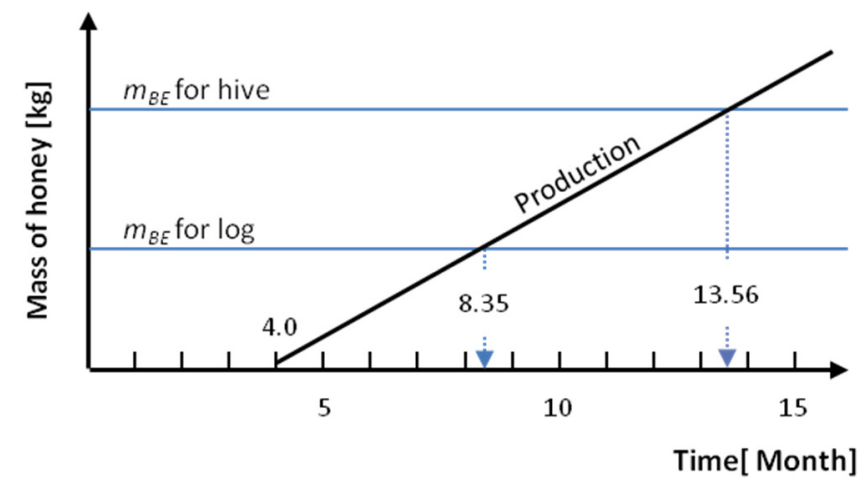

Fig. 2. Breakeven comparison of both system 


\section{Conclusion}

Investment in meliponiculture by log system and hive system with only honey sales as revenue was analyzed by engineering economic analysis. It was found that hive system has $40 \%$ higher capital cost, and log system has $22.7 \%$ higher EAUC. IRR of log system is $70 \%$, whereas hive system is $58 \%$, which is both has high return. Breakeven analysis shows that log system has 8.35 months of payback period, whereas hive system has 13.3 months of payback period. Although log system shows better results, if easiness of maintenance, colony splitting, and risks are considered, hive system could be a better choice. Both investment is economically viable in the current market price, and if sales of bee bread, propolis and by-products are considered, even better economic results could be obtained.

The authors would like to thank the Ministry of Education Malaysia for providing Research Grant under FRGS, RDU140119.

\section{References}

1. Hassan, Z. (2003). Aktiviti Keusahawanan Masyarakat Melayu pada Zaman Kegemilangan Kesultanan Melayu Melaka. In Seminar Za’ba Mengenai Alam Melayu (Nilai-nilai Peradaban Melayu). 1-21.

2. Idris, S. H. (2013). Tingkatkan Penghasilan Madu Lebah Tempatan. Agrobiz, 6.

3. Ismail, M. M. (2012). Honey Marketing in Malaysia, Agricultural Marketing Issues of Selected. Commodities.

4. Ismail, M. M. (2014). Competitiveness of Beekeeping Industry in Malaysia. Inaugural Lecture Series, Universiti Putra Malaysia.

5. Jaafar, M. F. (2011b). Penternakan Kelulut (Teknologi MARDI). Agromedia, 54-57.

6. Jaafar, M. F. (2012). Manual Teknologi Penternakan Lebah Kelulut. MARDI.

7. Sinar Harian (2016). Lalat askar hitam ancam kelulut. 23 July 2016.

8. Sinar Harian (2015). Sarang lebah kelulut dicuri. 27 April 2016. 